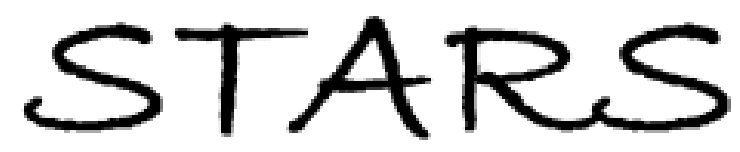

University of Central Florida

STARS

$1-1-2000$

\title{
Demand reduction in multiunit auctions: Evidence from a sportscard field experiment
}

John A. List

University of Central Florida

David Lucking-Reiley

Find similar works at: https://stars.library.ucf.edu/facultybib2000

University of Central Florida Libraries http://library.ucf.edu

This Article is brought to you for free and open access by the Faculty Bibliography at STARS. It has been accepted for inclusion in Faculty Bibliography 2000s by an authorized administrator of STARS. For more information, please contactSTARS@ucf.edu.

\section{Recommended Citation}

List, John A. and Lucking-Reiley, David, "Demand reduction in multiunit auctions: Evidence from a sportscard field experiment" (2000). Faculty Bibliography 2000s. 2522.

https://stars.library.ucf.edu/facultybib2000/2522

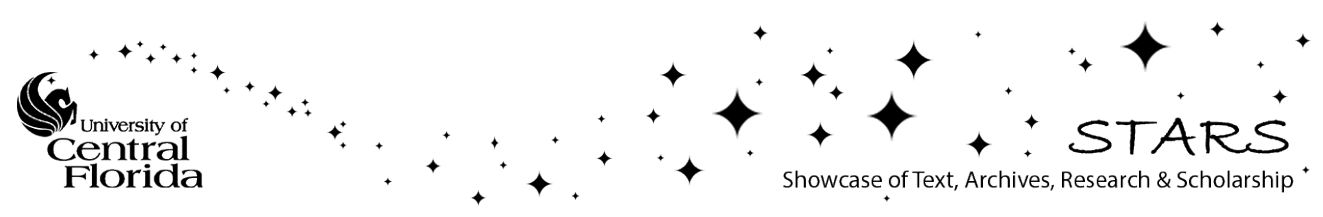




\title{
Demand Reduction in Multiunit Auctions: Evidence from a Sportscard Field Experiment
}

\author{
By John A. List and David Lucking-Reiley*
}

Recent auction theory suggests that multiunit uniform-price auctions, as used by the U.S. Treasury for debt sales, produce incentives that may cause bidders to bid less than their true valuations, resulting in inefficient allocations and reduced revenue. In this paper, we present the results of a field experiment in which we auction nearly $\$ 10,000$ worth of sportscards in two-unit, two-person sealed-bid auctions. We randomize participants into uniform-price and Vickrey auction treatments, and find underbidding in the uniform-price auctions' second-unit bids, as predicted. In contrast with theoretical predictions, however, we find that individuals' first-unit bids are significantly higher in the uniform-price than in the Vickrey treatment. The bid differences are large enough to affect the allocation of goods, as split allocations result significantly more often in the uniformprice treatment. We find no significant difference in revenues across auction formats.

Nearly four decades ago, William Vickrey (1961) illustrated the appealing features of secondprice sealed-bid auctions. In particular, he showed that second-price auctions induce "truthtelling" for bidders with independent private values (IPV); it is a dominant strategy for each bidder to reveal his or her maximum willingness to pay for the good. Hence, second-price auctions are allocatively efficient, as the bidder with the highest

* List: Department of Economics, University of Central Florida, 32765 (e-mail: John.List@bus.ucf.edu). LuckingReiley: Department of Economics, Vanderbilt University, Nashville, TN 37235 (e-mail: reiley@vanderbilt.edu). Lucking-Reiley gratefully acknowledges the National Science Foundation for support through Grant No. SBR9811273; we also acknowledge the List sportscard collection for generous contributions. Apinya Thumiphipol and Priti Manek provided research assistance. We thank two anonymous referees, Larry Ausubel, Catherine Co, Peter Cramton, Rachel Croson, Andrew Daughety, Richard Engelbrecht-Wiggans, Rob Godby, Brett Katzman, Rob Lemke, Dan Levin, Warren McHone, Charles Noussair, Jennifer Reinganum, Arlington Williams, and especially Jason Shogren for helpful comments. value always wins. In the same paper, Vickrey also considered the problem of a multiunit auction for $m$ units of a good. He demonstrated that full demand revelation will occur in a sealed-bid auction where each bidder submits one bid and the top $m$ bidders each win one good at a uniform price equal to the first bid rejected. He writes, "only in this way is it possible to insure that each bidder will be motivated to put in a bid at the full value of the article to himself, thus assuring an optimum allocation of resources." A number of economists used similar intuition when recommending the uniform-price sealed-bid format for its use in settings such as Treasury auctions. ${ }^{1}$

As Lawrence M. Ausubel and Peter C. Cramton (1996) point out, Vickrey's caveat in his very next paragraph went unnoticed by many economists:

It is important to realize, however, that this result applies only to cases where each bidder is interested in at most a single unit.... As soon as we consider the more general case where an individual bidder may be interested in securing two or more of the units, where the number of bidders is still too few to produce a fully competitive market, the possibility [of a] Pareto-optimal result ... disappears.

Vickrey did not find a solution to the problem of a demand-revealing auction with multiunit bidders, but Edward H. Clarke (1971) and Theodore Groves (1973) later provided general principles for revelation mechanisms, which can be applied to derive the correct multiunit generalization for the Vickrey auction. Specifically, the rules for an $m$-object Vickrey auction are that bidders can submit as many individualunit bids as they like, that the top $m$ bids will be declared winners, and that for the $k$ th unit won by a bidder, she or he must pay an amount equal

\footnotetext{
${ }^{1}$ For more details on recommendations of uniform-price auctions by economists, see Ausubel and Cramton (1996).
} 
to the $k$ th highest of the rejected bids submitted by others. ${ }^{2}$ When each bidder has demand for only a single unit of the good, this mechanism reduces to a uniform price auction.

Several authors have recently investigated equilibria in uniform-price auctions with multiunit demand, including Brett E. Katzman (1995), Charles Noussair (1995), Richard Engelbrecht-Wiggans and Charles M. Kahn (1998), and Ausubel and Cramton (1996). The first three consider situations where each bidder has private values for up to two units of the auctioned good, and give examples where the predicted equilibrium involves demand reduction-second-unit bids are lower than true valuations. Engelbrecht-Wiggans and Kahn (1998) provide a general characterization of equilibria in such environments. They show that bidders have a dominant strategy of truthtelling on the first unit of the good, and of demand reduction (at least weakly) on the second unit. Demand reduction is strictly greater than zero in many circumstances, including the case where both bidders' valuations are drawn independently from the same distribution. They also provide necessary conditions for the existence of "singleunit bid" equilibria, where each bidder submits a bid of zero on the second unit; in the extreme, such equilibria can result in zero revenues for the auctioneer.

Ausubel and Cramton (1996) present a general theory of demand reduction and inefficiency in multiunit auctions. They generalize previous multiunit demand models by allowing each individual to demand an arbitrary number of units and by allowing valuations to be correlated. To simplify the analysis, they assume that the auctioned good is infinitely divisible rather than discrete. Ausubel and Cramton provide sufficient conditions for demand reduction (and hence inefficiency) ${ }^{3}$ in a

\footnotetext{
${ }^{2}$ Technically, these rules are demand revealing only in cases where every bidder's demand curve is either flat or downward sloping, as is assumed in the theoretical papers cited here. If bidders might have upward-sloping demands (increasing returns to scale in purchases), then this simple price rule no longer works; a slightly more complicated set of instructions would be required to implement a GrovesClarke truthtelling mechanism.

${ }^{3}$ Allocative inefficiency results from demand reduction because high-value bidders who reduce their bids below their valuations potentially are outbid by bidders with lower valuations. For example, a bidder with high values on both
}

uniform-price auction: as long as at least one bidder has downward-sloping demand, any Nash equilibrium is guaranteed to have bid reduction. They also show that the revenue ranking of Vickrey and uniform-price auctions is ambiguous, depending on the underlying distribution of valuations. For most "standard" IPV probability distributions (those with a nondecreasing hazard rates, such as the uniform), however, they predict the Vickrey auction should revenue-dominate the uniform price auction.

Our work compares the multiunit Vickrey format to the uniform price format in a field experiment, contributing to the empirical literature on multiunit auctions. Several laboratory experiments have investigated multiunit auctions with singleunit demand, where demand reduction is not an issue (James C. Cox et al., 1984, 1985; Kevin A. McCabe et al., 1990, 1991). Paul Alsemgeest et al. (1998) find some demand reduction in the laboratory, in a dynamic ascending version of a uniformprice auction whose equilibrium is unknown. Ausubel and Cramton (1999) argue that the simultaneous ascending FCC auction format is strategically similar to a uniform-price sealed-bid auction, and present field data from the FCC spectrum auctions that are suggestive of demand reduction. Catherine D. Wolfram (1998) analyzes data from uniform-price auctions for electricity supply in England and Wales, finding evidence of the strategic behavior predicted by theory. The generators' marginal bids overstated their true marginal costs, an effect analogous to "demand reduction" in a supply auction. ${ }^{4}$

Our study complements the closely related paper by John H. Kagel and Dan Levin (2000).

first and second units will often win the first unit but lose the second unit to a bidder whose second-unit valuation is lower.

${ }^{4}$ Other multiunit studies include those by Gary J. Miller and Charles R. Plott (1985), who focus on revenue comparisons between uniform-price and discriminatory auctions in the laboratory. Rafael Tenorio (1993) and Steven R. Umlauf (1993) perform similar revenue comparisons with field data on Zambian currency auctions and Mexican Treasury bill auctions, respectively. Some recent laboratory experiments have explored auction environments with subjects selling multiple units of dissimilar goods (List and Shogren, 1998b) and buying multiple units of dissimilar, complementary goods (David Brenner and John Morgan, 1997; John O. Ledyard et al., 1997; Charles R. Plott, 1997; Mark Isaac and Duncan James, 1999). 
Their laboratory experiment looked for demand reduction by comparing the uniform price sealed-bid format with Ausubel's (1997) ascending-bid version of the Vickrey auction. The experiment was carefully designed to satisfy Ausubel and Cramton's (1996) sufficient conditions for demand reduction: a single twounit human bidder competed against robot bidders with unit demand (thus, the robots' demands were downward sloping). Confirming the theory, Kagel and Levin (2000) observed systematic bid reduction by human subjects on their second units in uniform-price auctions, by comparison both with actual values and with strategies observed in the Vickrey/Ausubel auction. However, they also observed overbidding relative to the dominant strategy on both units in the uniform-price sealed-bid auction, an effect unpredicted by theory but common to other sealed-bid laboratory studies. ${ }^{5}$ A third treatment, an ascending-bid implementation of the uniform price auction, eliminated the sealed-bid overbidding effect and produced more striking demand reduction. Kagel and Levin (2000) find that although efficiency is higher in the Vickrey/ Ausubel auction than in the uniform-price sealed-bid auction, revenues are higher in the uniform-price sealed-bid auction.

Our experiment differs from that of Kagel and Levin in four important ways. First, we test the uniform-price sealed-bid auction against the Vickrey sealed-bid auction, whereas Kagel and Levin run the dynamic (Ausubel) version of the Vickrey auction. Second, we have two human bidders per auction, rather than a single human versus a robot. Third, we use real goods rather than induced values. Fourth, we perform the experiment in the field rather than in the laboratory.

Our field experiments are most similar in methodology to those of List and Jason F. Shogren (1998a) and List et al. (1998), who use card-show experiments to investigate questions of contingent valuation. Field experiments present a trade-off: they give up some of the controls of a laboratory experiment (such as

\footnotetext{
${ }^{5}$ See, for example, Cox et al. (1985), Kagel et al. (1987), and Kagel and Levin (1993). Remarkably, Kagel and Levin (2000) still found this effect despite specifically instructing subjects that overbidding valuations could never increase profits, only reduce them.
}

induced valuations, or robots guaranteed to play equilibrium strategies against human subjects) in exchange for increased realism. ${ }^{6}$ Our experiments match the real-world settings that auction theory attempts to explain: our bidders compete for real goods rather than explicit cash values, they are not told explicitly the distributions of other's valuations, and they are likely to have previous experience bidding for the types of goods being auctioned. ${ }^{7}$ Field experiments provide a useful middle ground between the tight controls of the laboratory and the vagaries of completely uncontrolled field data.

\section{Experimental Design}

We designed our experiment to compare outcomes in uniform-price and Vickrey sealed-bid auctions, with particular attention to the question of demand reduction. We conducted equal numbers of Vickrey and uniform-price auctions, with different bidders in each auction. We also experimented with bidder type, conducting some of our experiments with professional card dealers and others with nondealers. This treatment was designed to capture the distinction between the theoretical cases of bidders with steep downward-sloping demands (individual consumers) and those with relatively flat demands (dealers) for multiple identical units. The auctioned sportscards fit into two price categories: low (book value of \$3) and high (book value of \$70). We conducted our treatments in June 1998, at a sportscard show in Orlando, FL, where we had a ready supply of card collectors interested in bidding in the auctions.

For the low-priced card auctions we chose a Joe Montana 1982 Topps football card and a 1989 Michael Jordan Hoops basketball card.

\footnotetext{
${ }^{6}$ Lucking-Reiley (1999a, b) gives up even more control in his field experiments, using Internet-based auctions in a preexisting market with an unknown number of participating bidders. These papers test the theory of revenue equivalence between four different single-unit auction formats, and the theory of reserve prices in first-price sealed-bid auctions.

${ }^{7}$ Given the proliferation of sportscard auctions, we feel we can safely assume that most of our participants (all recruited at a sportscard trade show) have previous experience bidding in auctions for such goods. For example, see Sports Collectors' Digest, a weekly publication filled with sportscard and sports memorabilia auctions.
} 
Both cards had a June 1998 book value of \$3. For the higher-priced auctions we selected a Cal Ripken, Jr. 1982 Topps baseball card and a Barry Sanders 1989 Score football card. These two cards had book values of approximately $\$ 70$. We sold dozens of each type of card, with all the cards in identical condition. All lowerpriced cards were independently graded by a sportscard dealer as "near-mint," and each higher-priced card was graded as "PSA 8 near-mint" by a well-known agency, Professional Sports Authenticators (PSA). ${ }^{8}$ All auctions for a given card type displayed the same sportscards to bidders, and identical copies were sold to winning bidders after the auctions concluded.

For the simplest possible test of demandreduction theory, we chose a design with two bidders and two goods per auction. We invited two bidders to submit two bids each for two identical sportscards, in an auction with no reserve price. We chose the auction format and card type for each subject according to a prespecified plan, to avoid accidentally introducing experimenter bias. After receiving bids from subjects within a given treatment, we randomly matched pairs of bidders to determine the outcome of each two-person auction. No participant bid in more than one auction. Our design is intended for between-subject comparisons; we draw our subjects from the same population and test whether the auction treatment has statistically significant effects on the average behavior of the population. ${ }^{9}$

Each participant's experience followed four steps: 1) inspection of the good, 2) learning the auction rules, 3) placing two bids, and 4) conclusion of the transaction. In step 1, a potential sub-

\footnotetext{
${ }^{8}$ Since PSA charges a grading fee of $\$ 10$ per card, we chose not to have the $\$ 3$ cards graded by PSA.

${ }^{9}$ Ideally, we would obtain data on a single subject bidding on the same card type in the two different auction formats, to do within-subject comparisons. However, doing the two auctions in sequence would most likely have changed bidders' demands for the goods (as two cards would already have been awarded by the time the second auction took place), thus destroying the ability to compare the two auction formats while holding all else equal. We considered collecting bids in both treatments from the same subject and randomizing which auction would actually "count" toward a real transaction, but rejected this idea in favor of keeping the environment as simple and realistic as possible. By explaining only one format to each bidder, we felt we would reduce the possibility of confusion.
}

ject approached the experimenter's table and inquired about the sale of the two sportscards displayed on the table. The experimenter then invited the potential subject to take about 5 minutes to participate in an auction for the two sportscards. If she agreed to participate, the subject could pick up and visually examine each card (in a sealed cardholder, with the graded card condition clearly marked). The experimenter worked one-on-one with the participant and imposed no time limit on inspection of the cards.

In step 2, the administrator gave the participant an instruction sheet that consisted of two parts: 1) an auction rules sheet, which also included a practice worksheet, and 2) a bidding sheet. ${ }^{10}$ In each auction type we informed the bidders that card dealers would bid against one other card dealer and nondealers would bid against one other nondealer. We changed the auction format and card type at the top of each hour, so subjects were assigned to each treatment based on the time they visited our table. The instruction sheets were identical across treatments, except for the explanations of the pricing rules.

In the uniform-price treatment, subjects read that "For each card won, the purchase price is equal to the amount of the third-highest bid (that is, the highest losing bid)," and they saw an example with bids ranked and labeled \$A, \$B, \$C, and \$D. In the Vickrey treatment, subjects read that "For each card won, the purchase price will be determined as follows. For the first unit you win, you pay an amount equal to the highest rejected bid which was not your own. For the second unit you win, you pay an amount equal to the second-highest rejected bid which was not your own." Because this rule is relatively complicated, they saw three different examples to illustrate possible outcomes with bids labeled \$A, \$B, \$C, and \$D. We avoided using actual dollar amounts in the examples, to avoid anchoring of bids.

After reading the auction rules, each participant worked through a bidding worksheet where each was asked to make up two numeric bids for each of two bidders, then to compute

\footnotetext{
${ }^{10}$ Verbatim copies of the experimental instructions are available for download at <http://www.vanderbilt.edu/ econ/reiley/>.
} 
TABle 1 -EXPERIMENTAL Design

\begin{tabular}{|c|c|c|c|c|c|}
\hline \multirow[b]{2}{*}{ Card } & \multirow{2}{*}{$\begin{array}{l}\text { Book } \\
\text { value }\end{array}$} & \multicolumn{2}{|c|}{ Nondealers $^{\mathrm{a}}$} & \multicolumn{2}{|c|}{ Dealers $^{\mathrm{a}}$} \\
\hline & & Uniform & Vickrey & Uniform & Vickrey \\
\hline $\begin{array}{l}\text { Barry Sanders } \\
1989 \text { Score }\end{array}$ & $\$ 70$ & 17 & 17 & - & - \\
\hline $\begin{array}{l}\text { Cal Ripken, Jr. } \\
1982 \text { Topps }\end{array}$ & $\$ 70$ & - & - & 15 & 15 \\
\hline $\begin{array}{l}\text { Michael Jordan } \\
1989 \text { Hoops }\end{array}$ & $\$ 3$ & 25 & 25 & - & - \\
\hline $\begin{array}{l}\text { Joe Montana } \\
1982 \text { Topps }\end{array}$ & $\$ 3$ & 15 & 15 & 10 & 10 \\
\hline
\end{tabular}

${ }^{\text {a }}$ Each auction had two invited bidders who submitted up to two bids each. The numbers in the cells represent the number of auctions run for each treatment type. For example, with 1989 Score Barry Sanders cards we ran 17 uniform-price auctions and 17 Vickrey auctions, with two cards each, for a total of 68 Barry Sanders cards sold.

the final allocation and prices paid. The experimenter checked the participant's answers to ensure that the subject understood the auction rules. After having her questions answered, the participant placed the two official bids on the bidding sheets (step 3$).^{11}$

Finally, in step 4 the experimenter explained that the bidder should return at a specified time (within several hours) to find out the results of the auction and conduct any resulting transactions. Transactions took place at 1:00 p.m. and 5:00 p.m. both Saturday and Sunday. If a winning bidder did not return for the specified transaction time, the bidder would be contacted by phone within three days after the show to complete the transaction. Upon receipt of payment, we would pay the postage required to send the card(s) in the mail to the winning bidder.

The dealer treatments took place in the same way as the nondealer treatments, with one exception. Instead of waiting for participants to arrive at the auction booth, the experimenter visited each dealer at his booth before the sportscard show opened, alternating the auction

\footnotetext{
${ }^{11}$ In laboratory experiments, more than one trial is often required before people understand the nature of certain auction mechanisms. We decided to use a one-shot auction so we could run the experiment on the floor of the sportscard show. To test whether subjects understood the auction mechanism, we ran a pilot study in May 1998 at a similar sportscard show in Orlando. On completion of these hypothetical auctions, subjects answered questions about their understanding of the auction rules. Approximately 15 people took part in each auction type, and no one had any problem understanding the allocation and price rules.
}

format and card type. The nondealer treatments took approximately 15 hours to complete (9:30 a.m. to 5:00 p.m. on Saturday and Sunday), whereas the dealer treatments took only $21 / 2$ hours (7:00 a.m. to 9:30 a.m. on Saturday). ${ }^{12}$

Table 1 shows the number of auctions of each type in our experimental design. In total, we ran 164 different two-unit auctions, including 82 uniform-price and 82 Vickrey. We auctioned 328 sportscards with a total book value of nearly $\$ 10,000$.

\section{Results}

We test several predictions of the theory of demand reduction discussed earlier. First, we expect to observe lower second-unit bids in the uniform price auction compared with the Vickrey auction. ${ }^{13}$ Second, we expect no difference be-

\footnotetext{
12 The dealer sessions were completed in a more timely fashion because the dealers (in their booths setting up their own cards) were more accessible, and they understood the auction rules more quickly than the nondealers (a number of the dealers actually run auctions themselves). To discourage collusion and/or information asymmetries, we swore each of the dealers to secrecy about our cards and auction formats. (Collusion was unlikely to be a factor anyway, with 100 dealers and over 200 nondealers matched randomly in pairs in our experiments.)

${ }^{13}$ Demand reduction is not guaranteed by Ausubel and Cramton's (1996) inefficiency theorem in our experiments; it is difficult to guarantee in an auction for real goods that at least one bidder has downward-sloping demand. However, the existence (if not uniqueness) of demand-reduction equilibria is predicted by the theory, and our study aims to detect whether this is a measurable effect.
} 
TABLE 2-Bids AND REVENUES

\begin{tabular}{|c|c|c|c|c|c|c|c|c|}
\hline \multicolumn{9}{|c|}{ Panel A: Descriptive statistics ${ }^{a}$} \\
\hline & \multicolumn{2}{|c|}{$\operatorname{Bid} 1^{\mathrm{b}}$} & \multicolumn{2}{|c|}{$\operatorname{Bid} 2^{\mathrm{c}}$} & \multicolumn{2}{|c|}{$\operatorname{Bid} 1-\operatorname{Bid} 2^{\mathrm{d}}$} & \multicolumn{2}{|c|}{ Revenue $^{e}$} \\
\hline & Vickrey & Uniform & Vickrey & Uniform & Vickrey & Uniform & Vickrey & Uniform \\
\hline Sanders $(\mathrm{ND})^{\mathrm{f}}$ & $\begin{array}{r}\$ 51.82 \\
(23.44)\end{array}$ & $\begin{array}{r}\$ 62.35 \\
(25.67)\end{array}$ & $\begin{array}{r}\$ 28.82 \\
(19.98)\end{array}$ & $\begin{array}{r}\$ 16.62 \\
(15.40)\end{array}$ & $\begin{array}{r}\$ 23.00 \\
(19.68)\end{array}$ & $\begin{array}{r}\$ 45.74 \\
(25.71)\end{array}$ & $\begin{array}{r}\$ 51.06 \\
(34.03)\end{array}$ & $\begin{array}{r}\$ 48.71 \\
(32.26)\end{array}$ \\
\hline Ripken (D) & $\begin{array}{c}49.60 \\
(15.19)\end{array}$ & $\begin{array}{c}62.67 \\
(15.28)\end{array}$ & $\begin{array}{c}41.77 \\
(14.46)\end{array}$ & $\begin{array}{c}30.60 \\
(13.43)\end{array}$ & $\begin{array}{c}7.83 \\
(9.16)\end{array}$ & $\begin{array}{c}32.07 \\
(20.13)\end{array}$ & $\begin{array}{c}72.87 \\
(25.26)\end{array}$ & $\begin{array}{c}76.13 \\
(21.31)\end{array}$ \\
\hline Jordan (ND) & $\begin{array}{c}1.73 \\
(1.51)\end{array}$ & $\begin{array}{c}1.83 \\
(1.35)\end{array}$ & $\begin{array}{c}0.91 \\
(1.04)\end{array}$ & $\begin{array}{c}0.82 \\
(0.85)\end{array}$ & $\begin{array}{c}0.82 \\
(1.11)\end{array}$ & $\begin{array}{c}1.02 \\
(1.18)\end{array}$ & $\begin{array}{c}1.13 \\
(1.52)\end{array}$ & $\begin{array}{c}1.71 \\
(1.34)\end{array}$ \\
\hline Montana (D) & $\begin{array}{c}2.03 \\
(0.86)\end{array}$ & $\begin{array}{c}2.49 \\
(2.18)\end{array}$ & $\begin{array}{c}1.26 \\
(0.84)\end{array}$ & $\begin{array}{c}0.94 \\
(0.85)\end{array}$ & $\begin{array}{c}0.77 \\
(0.56)\end{array}$ & $\begin{array}{c}1.55 \\
(2.22)\end{array}$ & $\begin{array}{c}2.37 \\
(1.33)\end{array}$ & $\begin{array}{c}2.13 \\
(1.09)\end{array}$ \\
\hline Montana (ND) & $\begin{array}{c}1.37 \\
(1.33)\end{array}$ & $\begin{array}{c}1.40 \\
(1.44)\end{array}$ & $\begin{array}{c}0.47 \\
(0.53)\end{array}$ & $\begin{array}{c}0.42 \\
(0.61)\end{array}$ & $\begin{array}{c}0.90 \\
(1.20)\end{array}$ & $\begin{array}{c}0.98 \\
(1.20)\end{array}$ & $\begin{array}{c}0.66 \\
(0.69)\end{array}$ & $\begin{array}{c}0.83 \\
(1.00)\end{array}$ \\
\hline
\end{tabular}

Panel B: Hypothesis tests for equality between Vickrey and uniform-price formats ${ }^{\mathrm{g}}$

\begin{tabular}{lcrrr} 
& Bid 1 & Bid 2 & Bid 1-Bid 2 & Revenues \\
\hline Sanders (ND) & $t=-1.77$ & $t=2.82$ & $t=-4.09$ & $t=-0.21$ \\
& $p=0.077$ & $p=0.005$ & $p=0.000$ & $p=0.836$ \\
Ripken (D) & $t=-3.32$ & $t=3.10$ & $t=-6.00$ & $t=-0.38$ \\
& $p=0.002$ & $p=0.001$ & $p=0.000$ & $p=0.702$ \\
Jordan (ND) & $t=-0.38$ & $p=0.47$ & $t=-0.86$ & $t=-1.42$ \\
& $p=0.706$ & $t=1.19$ & $p=0.391$ & 0.156 \\
Montana (D) & $p=-0.88$ & $t=0.235$ & $p=-1.52$ & $p=0.44$ \\
& $p=0.377$ & $t=0.34$ & $t=0.128$ & $t=-0.54$ \\
Montana (ND) & $t=-0.08$ & $p=0.733$ & $p=0.800$ & $p=0.588$
\end{tabular}

\footnotetext{
${ }^{\text {a }}$ Standard deviations of the data are in parentheses.

${ }^{\mathrm{b}}$ Bid 1 data consist of the first bid submitted by each bidder.

${ }^{\mathrm{c}}$ Bid 2 data consist of the second bid submitted by each bidder.

${ }^{\mathrm{d}}$ Bid 1-Bid 2 data consist of the difference between a bidder's first-unit bid and second-unit bid.

${ }^{\mathrm{e}}$ Revenue equals the total payment received for both cards in the auction.

${ }^{\mathrm{f}}$ (ND) denotes a nondealer treatment; (D) denotes a dealer treatment.

${ }^{\mathrm{g}}$ We present each $t$ statistic for the null hypothesis that the Vickrey bid minus the uniform-price bid equals zero, with the corresponding two-tailed $p$-value.
}

tween first-unit bids in the uniform-price auction and those in the Vickrey auction. Third, we expect to find more zero bids in the uniform-price treatment than in the Vickrey treatment. ${ }^{14}$ Finally, we expect revenues to be lower in the uniform-price auction than in the Vickrey auction. ${ }^{15}$

Table 2 reports summary statistics for our auction data. The first four columns of Panel A display means and standard deviations of the

\footnotetext{
${ }^{14}$ Engelbrecht-Wiggans and Kahn (1998) note, "we may observe fewer bids in such uniform-price auctions than in other forms of multi-unit auctions, a potentially testable implication." To our knowledge, this is the first study to test that hypothesis.

${ }^{15}$ As noted earlier, this prediction is not guaranteed by the theory, but it is true for the standard distributions used to provide concrete examples in auction theory.
}

bids submitted in each auction type. One pattern in the data is that first-unit bids are larger in the uniform-price auctions than in the corresponding Vickrey auctions. The magnitude of the difference is around $\$ 10$ for the high-priced (\$70) cards, and $\$ 0.03$ to $\$ 0.46$ for the lowpriced (\$3) cards. The ranking reverses for second-unit bids, supporting demand reduction theories: Vickrey second-unit bids are approximately $\$ 12$ higher than the corresponding uniform-price bids for high-priced cards, and $\$ 0.05$ to $\$ 0.30$ higher for the low-priced cards. Further evidence of demand reduction is contained in the next two columns of Panel A in Table 2, which present differences between first and second bids - a measure of the steepness of each bidder's downward-sloping bid schedule. In each treatment, the mean difference between 
first-unit and second-unit bids is much larger in the uniform-price auctions than in the Vickrey auctions. ${ }^{16}$

The rightmost columns of Panel A in Table 2 give descriptive statistics for auction revenues generated by each pair of cards. Mean revenues ranged from as low as 11 percent of book value (in nondealer auctions for low-priced cards) to as high as 54 percent of book value (in dealer auctions for high-priced cards); low revenues are unsurprising in auctions where only two randomly selected bidders competed for two cards. ${ }^{17}$ Dealer auctions had higher ratios of revenue to book value than did nondealer auctions; this probably indicates that nondealers tend to have lower demand schedules for the auctioned cards. There seems to be no systematic difference in revenues across auction formats.

We next present formal statistical tests of our hypotheses. The second panel of Table 2 contains $t$-statistics and two-tailed $p$-values for each of the hypotheses discussed below. ${ }^{18}$

\section{A. First-Unit and Second-Unit Bids}

One way to test for demand reduction is to examine first-unit bids and second-unit bids individually. Theory predicts that first-unit bids

\footnotetext{
${ }^{16}$ For example, differences between bid one and bid two were \$7-\$23 in the Vickrey auctions for expensive cards, compared with $\$ 30-\$ 45$ in the uniform price auctions. For the lower-priced cards, bids differed by $\$ 0.80-\$ 0.90$ in the Vickrey auctions, and $\$ 1.00-\$ 1.50$ in the uniform price auctions.

${ }^{17}$ To the extent that revenues are lower than could have been earned through another selling mechanism, this represents personal financial investment in the research by the experimenters. We could have invited more bidders to increase revenues and thereby save money, but we felt that a two-bidder environment gave us the best chance to observe demand reduction. Similarly, we might have used positive reserve prices to avoid selling cards at very low prices, but this would also have reduced our ability to observe demand reduction (by reducing the number of observed bids and narrowing the range of acceptable bids).

${ }^{18}$ We report results of a large-sample test, which does not require stringent assumptions about the exact shapes of the underlying distributions to generate a normally distributed test statistic. The large-sample assumption may be somewhat strained for our smallest pair of samples (only 20 observations per sample). As a robustness check, we also conducted small-sample $t$ tests that assume the populations have normal distributions and equal variances, and the results were not qualitatively different in any of the tests.
}

should be equal on average in the two auction formats, since both auctions have the same dominant strategy for first-unit bids, and that second-unit bids should be lower on average in the uniform-price format through strategic demand reduction. Because we are most interested in the presence of strategic demand reduction, we first examine second-unit bids. The corresponding column of Panel B in Table 2 shows that all five $t$-statistics have the expected positive sign, indicating that second bids were larger in the Vickrey auctions. The $p$-values indicate that this difference is statistically significant for the high-value $(\$ 70)$ cards $(p=0.005$, $0.001)$, but not for the low-value (\$3) cards $(p=0.638,0.235,0.733)$.

The results on first-unit bids, in the first column of Panel B in Table 2, also provide interesting insights. Despite the theoretical prediction of equality of first-unit bids across auction types, our point estimates show that first-unit bids are higher on average in the uniform-price auctions, and this is robust across all five treatments. These effects are similar in magnitude to the second-unit bid reduction found previously, but are opposite in sign. Formal tests again indicate statistical significance for the $\$ 70$ cards ( $p=0.077,0.002)$, but not for the $\$ 3$ cards $(p=0.706,0.377,0.937)$. We find the presence, not to mention the magnitude, of this effect quite surprising, because it is not predicted by any theory of which we are aware. Because we cannot observe valuations directly, this difference in first-unit bids could represent either overbidding in the uniformprice auction and/or underbidding in the Vickrey auction.

\section{B. Bid Schedules}

The previous subsection's evidence of demand reduction uses information on individuals' first- and second-unit bids. We can perform a potentially more powerful test of demand reduction by analyzing an individual's entire demand schedule. That is, we compute the difference between an individual's first-unit bid and her second-unit bid, and test whether the mean difference varies across auction treatments. Demand reduction theory predicts that the mean difference will be greater in the uniform-price treatment, since first-unit bids 
Table 3-Proportions of Zero Bids, of Flat-Bid Schedules, and of Split Allocations

\begin{tabular}{|c|c|c|c|c|c|c|c|c|}
\hline & \multicolumn{2}{|c|}{ Zeros on Bid $1^{\mathrm{a}}$} & \multicolumn{2}{|c|}{ Zeros on $\operatorname{Bid} 2^{b}$} & \multicolumn{2}{|c|}{ Flat-bid schedules ${ }^{c}$} & \multicolumn{2}{|c|}{ Split allocations ${ }^{\mathrm{d}}$} \\
\hline & Vickrey & Uniform & Vickrey & Uniform & Vickrey & Uniform & Vickrey & Uniform \\
\hline Sanders $(\mathrm{ND})^{\mathrm{e}}$ & 0.0 & 0.0 & 5.9 & 20.6 & 14.7 & 0.0 & 55.9 & 85.3 \\
\hline Ripken (D) & 0.0 & 0.0 & 0.0 & 3.3 & 36.7 & 6.7 & 23.3 & 86.7 \\
\hline Jordan (ND) & 12.0 & 4.0 & 34.0 & 30.0 & 32.0 & 22.0 & 32.0 & 54.0 \\
\hline Montana (D) & 0.0 & 0.0 & 10.0 & 25.0 & 20.0 & 5.0 & 60.0 & 45.0 \\
\hline Montana (ND) & 10.0 & 13.3 & 40.0 & 50.0 & 30.0 & 30.0 & 46.7 & 53.3 \\
\hline Overall & 5.5 & 3.7 & 20.1 & 26.2 & 27.4 & 14.0 & 41.5 & 65.2 \\
\hline
\end{tabular}

Notes: All values are expressed as percentages.

a "Zeros on bid 1" indicates the proportion of first-unit bids equal to zero.

b "Zeros on bid 2" is the corresponding proportion for second-unit bids.

c "Flat-bid schedules" denotes the proportion of bidders whose bid schedules are flat (first-unit bid equals second-unit bid).

d "Split allocations" indicates the proportion of auctions for which the two goods were split between the two bidders.

e (ND) denotes a nondealer treatment; (D) denotes a dealer treatment.

should be unaffected across treatments, whereas second-unit bids should be reduced in the uniform-price auction.

The third column in Panel B of Table 2 presents the results of this hypothesis test. For the high-value card treatments, bid differences are statistically significant $(p<0.001)$, as predicted. For each of the two low-value cards auctioned to nondealers the differences have the predicted sign but are statistically insignificant $(p=0.391,0.800)$. The evidence is stronger in the dealer treatment for the low-value card $(p=0.128)$, suggesting that dealers exhibit some demand reduction on the low-value cards as well as on the high-value cards. By contrast, the nondealers appear to exhibit demand reduction only on the high-value cards.

The bid-reduction effect appears to be more prominent when the stakes are higher. In light of recent research on decision making in the presence of cognitive costs, this finding is intuitively appealing. ${ }^{9}$ The results also suggest that with low-priced cards, dealers may be more likely to bid strategically, perhaps because they have to exert less effort to formulate optimal bidding strategies as dealers most likely have more experience with auctions. Though several laboratory experi-

\footnotetext{
${ }^{19}$ See Vernon L. Smith and James M. Walker (1993) for an example of such a theory and its application to experimental evidence. Robert Slonim and Alvin E. Roth (1998) present a recent example of higher stakes causing behavior to become more consistent with Nash equilibrium. John Conlisk (1996) provides a nice review of research on the topic of decision-making with deliberation costs.
}

ments have investigated the effects of the size of stakes, we believe ours is the first study to document a similar effect in the field.

A related test examines the proportion of flat bid schedules. Some bidders might value the second unit of a card just as much as the first one; we expect this to be particularly true for dealers, who can often resell the second unit of a card just as easily as the first. If such a bidder truthfully reveals her demand, we would expect the bid schedule to be completely flat (zero difference between first-unit and second-unit bids). The fifth and sixth columns of Table 3 report the proportion of bidders who submitted flat bid schedules.

Demand-reduction theory predicts that the proportion of flat-bid schedules should be lower in the uniform-price auction than in the Vickrey auction. Pooling across treatments, since this test does not rely on bid magnitudes, we find sample proportions of 23/164 (14 percent) and 45/164 (27.4 percent) for the uniform-price and Vickrey auctions. A test of the null hypothesis of equality yields a $p$-value of 0.003 , indicating that the uniform price auction yields significantly fewer flat bid schedules across the combined set of five treatments, as predicted.

\section{Zero Bids}

How extreme is the amount of demand reduction in our uniform-price auctions? As noted earlier, Engelbrecht-Wiggans and Kahn (1998) predict that a higher proportion of second-unit bids will equal zero in uniform-price auctions 
than in Vickrey auctions. This is strong demand reduction, a second-unit bid reducing all the way to zero. First-unit bids should be unaffected; the choice of auction format should cause more zeros only on second-unit bids. Columns 1-4 of Table 3 provide data on the number of bids equal to zero in each of the auction treatments. Since bid magnitudes do not matter in these tests, we pool data across card types. For first-unit bids, we received 9 zeros out of 164 bids (5.5 percent) in the Vickrey treatment, and $6 / 164$ (3.7 percent) in the uniform-price treatment. A formal statistical test indicates no significant difference between these proportions $(z=0.79$, two-tailed $p=0.428)$, which is consistent with the theoretical prediction. All 15 of the zeros received in first-unit bids occurred in the nondealer treatments with $\$ 3$ cards; this most likely indicates that those 15 individuals literally had zero demand for the cards. ${ }^{20}$

The more important test is that for secondunit bids. Here we see 33 of 164 bids (20.1 percent) equaling zero in the Vickrey treatment, compared with 43 of 164 (26.2 percent) in the uniform price treatment. This difference is not statistically significant at conventional levels $(z=-1.31, p=0.191)$. However, given our earlier results that suggest low stakes do not induce strategic behavior among nondealers, we chose to redo this test excluding the Montana and Jordan nondealer treatments. ${ }^{21}$ For the pooled data on the other three treatments, a formal test shows that the proportion of zero bids is significantly higher in the uniform-price auction format $(z=-3.22, p=0.001)$. Thus, at least in the treatments with high stakes or more experienced bidders, we find evidence of more zero bids in the uniform-price auction format, a result predicted by theory.

\section{Allocation of Goods}

Demand reduction matters most when it causes allocative inefficiency, moving the equilibrium allocation of goods away from the Pareto optimum.

\footnotetext{
${ }^{20}$ Given the earlier results on lack of demand reduction in the low-value nondealer treatments, this finding could also be a reflection of reduced rationality by nondealers in bidding for low-value cards.

${ }^{21}$ Note that this automatically excludes all observations with first-unit bids equal to zero.
}

Despite the clear statistical evidence of demand reduction in this study, the allocation effects might still be inconsequential. Demand-reduction theory predicts a single type of distortion from efficiency in a two-bidder, two-good uniform-price auction: a bidder with high values for both units reduces his/her bid so much on the second unit that a second bidder with strictly lower values manages to win one of the two goods. This split allocation of goods produces lower total surplus than would an allocation that gives both units to the highvalue bidder.

Because this is a field experiment, we do not observe bidders' true valuations for the goods and, therefore, we cannot provide a direct test of inefficiency. We can, however, observe whether allocations appear to be significantly different between the two auction formats: do uniform-price auctions result in more split allocations of the two goods than do Vickrey auctions? The data in the final two columns of Table 3 address this question.

With the exception of the dealer treatment for Joe Montana (\$3) cards, in every treatment the sample proportion of split allocations is higher for the uniform-price auction than for the Vickrey auction. In total, 34 of 82 auctions (41.5 percent) produced split allocations in the Vickrey treatment, compared with $53.5^{22}$ of 82 auctions (65.2 percent) in the uniform-price treatment. The pooled data allow us to reject the null hypothesis of equality between those proportions $(z=-5.31, p<0.001)$. Thus, the proportion of split allocations is significantly higher in uniform-price auctions than in Vickrey auctions. We conclude that demand reduction is large enough to have economically significant effects on allocative efficiency.

\section{E. Revenues}

Another natural question to ask is which auction format produces greater revenues. As noted earlier, the theoretical literature yields uncertain revenue rankings of the two auction formats,

\footnotetext{
${ }^{22}$ Some auctions were ambiguous in their allocation, because they had ties for the second-highest bid in the auction. In practice, we flipped a coin to determine the winner. For statistical purposes, we chose to classify such outcomes as 0.5 of a split allocation, since such outcomes were equally likely to result in splits as in two-unit packages.
} 
depending on the underlying structure of bidder demands, but the simplest examples tend to produce lower revenues in the uniform price auction. ${ }^{23}$ Data on revenues are in the rightmost columns in Panel A of Table 2, whereas results of hypothesis tests for each treatment can be found in Panel B of Table 2. The rankings are indeed ambiguous: two of the treatments produced higher mean Vickrey revenues, whereas three produced higher mean uniform-price revenues. In none of the cases was the revenue difference statistically significant. ${ }^{24}$

Kagel and Levin (2000) find that uniformprice auctions revenue-dominate ascendingformat Vickrey auctions, in a demand environment where the clear theoretical prediction was for the Vickrey auction to dominate. By contrast, we find that the uniform-price and Vickrey auctions cannot be revenue ranked. This could be the result of the difference between the laboratory and the field: demand conditions are known and regular in the laboratory, but unknown and potentially variable in the field. Indeed, Ausubel and Cramton (1996) show that the revenue rankings can depend critically on the underlying demand structure. Alternatively, the difference between our findings and those of Kagel and Levin could be because our Vickrey auctions were sealed bid, whereas their were ascending. Their results indicate that sealed-bid auctions generate overbidding relative to ascending auctions in general, so our comparison of two sealed-bid formats could have eliminated their revenue differences. We conclude that, at least for sportscard auctions, Vickrey sealed-bid auctions may be substituted for uniform-price auctions without an appreciable loss of revenue.

\section{Conclusion}

Multiunit auctions with multiunit demand are extremely important in practice, from Treasury bill auctions to FCC spectrum auctions to com-

\footnotetext{
${ }^{23}$ Extreme examples include the zero-bid equilibria of Engelbrecht-Wiggans and Kahn, where revenues are positive in the Vickrey auction but zero in the uniform-price auction.

${ }^{24}$ Our revenue results are likely to be the result, in part, of the two countervailing bid effects we found: first-unit bids favor the uniform-price auction, whereas second-unit bids favor the Vickrey auction.
}

mercial Internet auctions for computer equipment and other goods. A recent wave of auction theory has begun to model multiunit auctions in more detail, and in this paper we conduct empirical tests of this new body of multiunit auction theory. By running field auctions for sportscards using both the Vickrey and the uniform price sealed-bid auction formats, we test the theoretical prediction that demand reduction is an important factor in uniform-price auctions.

Our data yield several important findings. First, demand reduction is evident in the uniform-price auctions, relative to the Vickrey auctions. Second, the amount of demand reduction is frequently large: the uniform-price auction results in significantly more bids of zero and the bid reductions are large enough to cause frequent changes in the allocation of goods. ${ }^{25}$ Third, we find an anomalous result that does not conform to theoretical predictions: first-unit bids are higher in uniformprice auctions than in Vickrey auctions. Fourth, revenues are not systematically different across auction formats, so efficiency gains in the Vickrey auction do not come at the expense of reduced revenues for the seller.

We hope to see these results replicated and extended to more complicated environments. First, one could replicate the same experiments with induced values, to establish a more direct connection between the laboratory and the field. Second, one could consider increased numbers of bidders and goods, since multiunit auctions typically involve more than two bidders and more than two goods. Increased numbers of bidders might reduce demand-reduction effects, by decreasing the probability of one's own bid affecting the price. Increased numbers of goods might have the opposite effect, as the possibility of more units at a lower price could increase the incentives for demand reduction. We anticipate that future theoretical and empirical work will address these issues.

\footnotetext{
${ }^{25}$ Our finding of demand reduction has potentially broad implications. In addition to the well-publicized auctions for Treasury debt sales and communications spectrum rights, we note that WR Hambrecht + Co has recently announced uniform price auctions for initial public offerings of corporate shares through its OpenIPO Web site. Our results may also be relevant to auctions for pollution emission permits, especially in thin regional markets (see Timothy Cason and Charles Plott, 1996, and Robert Godby, 1998).
} 


\section{REFERENCES}

Alsemgeest, Paul; Noussair, Charles and Olson, Mark. "Experimental Comparisons of Auctions under Single- and Multi-Unit Demand." Economic Inquiry, January 1998, 36(1), pp. 87-97.

Ausubel, Lawrence M. “An Efficient AscendingBid Auction for Multiple Objects." Working paper, University of Maryland, 1997.

Ausubel, Lawrence M. and Cramton, Peter C. "Demand Reduction and Inefficiency in Multi-Unit Auctions." Working paper, University of Maryland, 1996.

Brenner, David and Morgan, John. "The VickreyClarke-Groves versus the Simultaneous Ascending Auction: An Experimental Approach." Working paper, Princeton University, 1997.

-Cason, Timothy N. and Plott, Charles R. "EPA's New Emissions Trading Mechanism: A Laboratory Evaluation." Journal of Environmental Economics and Management, March 1996, 30(2), pp. 133-60.

-Clarke, Edward H. "Multipart Pricing of Public Goods." Public Choice, Fall 1971, 11, pp. 17-33.

Conlisk, John. "Why Bounded Rationality?" Journal of Economic Literature, June 1996, 34(2), pp. 669-700.

Cox, James C.; Smith, Vernon L. and James M. Walker. "Theory and Behavior of Multiple Unit Discriminative Auctions." Journal of Finance, September 1984, 39(4), pp. 983-1010.

. "Expected Revenue in Discriminative and Uniform Price Sealed Bid Auctions," in Vernon L. Smith, ed., Research in experimental economics, Vol. 3. Greenwich, CT: JAI Press, 1985, pp. 183-232.

Engelbrecht-Wiggans, Richard and Kahn, Charles M. "Multi-Unit Auctions with Uniform Prices." Economic Theory, September 1998, 12(2), pp. 227-58.

Godby, Robert. "Market Power, Vertical Markets and Laboratory Emission Permit Double Auctions." Working paper, University of Wyoming, 1998.

-Groves, Theodore. "Incentives in Teams." Econometrica, July 1973, 41(4), pp. 617-31.

Isaac, Mark, and James, Duncan. "Robustness of the Incentive Compatible Combinatorial Auction," Working paper, University of Arizona, 1999.
-Kagel, John H.; Harstad, Ronald M. and Levin, Dan. "Information Impact and Allocation Rules in Auctions with Affiliated Private Values: A Laboratory Study." Econometrica, November 1987, 55(6), pp. 1275-304.

-Kagel, John H., and Levin, Dan. "Independent Private Value Auctions: Bidder Behavior in First-, Second-, and Third-Price Auctions with Varying Numbers of Bidders." Economic Journal, July 1993, 103(419), pp. $868-79$.

"Behavior in Multi-Unit-Demand Auctions: Experiments with Uniform-Price and Dynamic Auctions." Econometrica, 2000 (forthcoming).

Katzman, Brett Eric. "Multi-Unit Auctions with Incomplete Information." Working paper, University of Miami, 1995.

Ledyard, John O.; Porter, David and Rangel, A. "Experiments Testing Multiobject Allocation Mechanisms." Journal of Economics and Management Strategy, Fall 1997, 6(3), pp. 639-75.

List, John A.; Margolis, M. and Shogren, Jason F. "Hypothetical-Actual Bid Calibration of a Multi-Good Auction." Economics Letters, September 1998, 60(3), pp. 263-68.

-List, John A. and Shogren, Jason F. "Experimental Calibration of the Difference between Actual and Hypothetical Reported Valuations," Journal of Economic Behavior and Organization, October 1998a, 37(2), pp. 193-205. - "The Deadweight Loss of Christmas: Comment," American Economic Review, December 1998b, 88(5), pp. 1350-55.

-Lucking-Reiley, David. "Using Field Experiments to Test Equivalence Between Auction Formats: Magic on the Internet." American Economic Review, December 1999, 89(5), pp. $1063-80$.

- "Magic on the Internet: Evidence from Field Experiments on Reserve Prices in Auctions." Working Paper, Vanderbilt University, 1999b.

McCabe, Kevin A.; Rassenti, Stephen J. and Smith, Vernon L. "Auction Institutional Design: Theory and Behavior of Simultaneous MultipleUnit Generalizations of the Dutch and English Auctions." American Economic Review, December 1990, 80(5), pp. 1276-83. . "Testing Vickrey's and Other Simultaneous Multiple Unit Versions of the 
English Auction," in Vernon L. Smith, ed., Research in experimental economics, Vol. 4. Greenwich, CT: JAI Press, 1991, pp. 45-79.

Miller, Gary J. and Plott, Charles R. "Revenue Generating Properties of Sealed-Bid Auctions: An Experimental Analysis of OnePrice and Discriminative Processes," in Vernon L. Smith, ed., Research in experimental economics, Vol. 3. Greenwich, CT: JAI Press, 1985, pp. 159-81.

Noussair, Charles. "Equilibria in a Multi-object Uniform Price Sealed Bid Auction with Multi-unit Demands." Economic Theory, 1995, 5(2), pp. 337-51.

-Plott, Charles R. "Laboratory Experimental Testbeds: Application to the PCS Auction." Journal of Economics and Management Strategy, Fall 1997, 6(3), pp. 605-38.

Slonim, Robert and Roth, Alvin E. "Learning in High Stakes Ultimatum Games: An Experiment in the Slovak Republic." Econometrica, May 1998, 66(3), pp. 569-96.
-Smith, Vernon L. and Walker, James M. "Monetary Rewards and Decision Cost in Experimental Economics." Economic Inquiry, April 1993, 31(2), pp. 245-61.

Tenorio, Rafael. "Revenue Equivalence and Bidding Behavior in a Multi-Unit Auction Market: An Empirical Analysis." Review of Economics and Statistics, May 1993, 75(2), pp. 302-14.

Umlauf, Steven R. "An Empirical Study of the Mexican Treasury Bill Auction." Journal of Financial Economics, June 1993, 33(3), pp. 313-240.

Vickrey, William. "Counterspeculation, Auctions, and Competitive Sealed Tenders." Journal of Finance, 16(1), March 1961, pp. 8-37.

-Wolfram, Catherine D. "Strategic Bidding in a Multiunit Auction: An Empirical Analysis of Bids to Supply Electricity in England and Wales." Rand Journal of Economics, Winter 1998, 29(4), pp. 703-25.

WR Hambrecht+Co. OpenIPO Web site. 〈http:// www.openipo.com/ $/$. 


\section{This article has been cited by:}

1. Gautam Gupta. 2019. Experiments in Economics: A Survey. Studies in Microeconomics 173, 232102221984275. [Crossref]

2. Noah Dormady, Paul J. Healy. 2019. The consignment mechanism in carbon markets: A laboratory investigation. Journal of Commodity Markets 14, 51-65. [Crossref]

3. Duy Nong. 2019. A general equilibrium impact study of the Emissions Reduction Fund in Australia by using a national environmental and economic model. Journal of Cleaner Production 216, 422-434. [Crossref]

4. Marco Pagnozzi, Krista J. Saral. 2019. Efficiency in auctions with (failed) resale. Journal of Economic Behavior \& Organization 159, 254-273. [Crossref]

5. Yangguang Huang, Quan Wen. 2019. AUCTION-LOTTERY HYBRID MECHANISMS: STRUCTURAL MODEL AND EMPIRICAL ANALYSIS. International Economic Review 60:1, 355-385. [Crossref]

6. Takehito Masuda, Toyotaka Sakai, Shigehiro Serizawa, Takuma Wakayama. 2019. A Strategy-Proof Mechanism Should Be Announced to Be Strategy-Proof: An Experiment for the Vickrey Auction. SSRN Electronic Journal . [Crossref]

7. Jack Fanning, Andrew Kloosterman. 2019. A Simple Experimental Test of the Coase Conjecture: Fairness in Dynamic Bargaining. SSRN Electronic Journal . [Crossref]

8. Georgia Kosmopoulou, Daniel Nedelescu, Fletcher Rehbein. Panel Data Analysis Based on Lab Evidence in Auction Market Experiments 521-545. [Crossref]

9. Duy Nong, Mahinda Siriwardana. 2018. Potential impacts of the Emissions Reduction Fund on the Australian economy. Energy Economics 74, 387-398. [Crossref]

10. Ernan Haruvy, Peter T.L. Popkowski Leszczyc. 2018. A Study of Bidding Behavior in Voluntary-Pay Philanthropic Auctions. Journal of Marketing 82:3, 124-141. [Crossref]

11. Emi Uchida, Stephen K. Swallow, Arthur J. Gold, James Opaluch, Achyut Kafle, Nathaniel H. Merrill, Clayton Michaud, Carrie Anne Gill. 2018. Integrating Watershed Hydrology and Economics to Establish a Local Market for Water Quality Improvement: A Field Experiment. Ecological Economics 146, 17-25. [Crossref]

12. Patrick Hummel. 2018. How do selling mechanisms affect profits, surplus, capacity and prices with unknown demand?. Canadian Journal of Economics/Revue canadienne d'économique 51:1, 94-126. [Crossref]

13. Yangguang Huang, Quan Wen. 2018. Auction-Lottery Hybrid Mechanisms: Structural Model and Empirical Analysis. SSRN Electronic Journal . [Crossref]

14. Marco Pagnozzi, Krista J. Saral. 2017. Demand Reduction in Multi-Object Auctions with Resale: An Experimental Analysis. The Economic Journal 127:607, 2702-2729. [Crossref]

15. Peter Cramton, Axel Ockenfels. 2017. The German 4G Spectrum Auction: Design and Behaviour. The Economic Journal 127:605, F305-F324. [Crossref]

16. Janne Tukiainen. 2017. Effects of Minimum Bid Increments in Internet Auctions: Evidence from a Field Experiment. The Journal of Industrial Economics 65:3, 597-622. [Crossref]

17. Duy Nong, Mahinda Siriwardana. 2017. Australia's Emissions Reduction Fund in an international context. Economic Analysis and Policy 54, 123-134. [Crossref]

18. Oleksandr DYBA, Oleksandr KIKOT. 2017. Methodological issues of experimental evaluation of securities auctions. Naukovi pratsi NDFI 2017:1, 97-106. [Crossref]

19. O. Al-Ubaydli, J.A. List. Field Experiments in Markets 271-307. [Crossref] 
20. Anna Bayona, Xavier Vives. 2017. Supply Function Competition, Private Information, and Market Power: A Laboratory Study. SSRN Electronic Journal . [Crossref]

21. Noah Dormady. 2017. Carbon Auctions, Energy Markets and Market Power: An Experimental Analysis. SSRN Electronic Journal . [Crossref]

22. Erin Hobin, Heather Lillico, Fei Zuo, Jocelyn Sacco, Laura Rosella, David Hammond. 2016. Estimating the impact of various menu labeling formats on parents' demand for fast-food kids' meals for their children: An experimental auction. Appetite . [Crossref]

23. Daniel L. Chen, Martin Schonger, Chris Wickens. 2016. oTree-An open-source platform for laboratory, online, and field experiments. Journal of Behavioral and Experimental Finance . [Crossref]

24. Abel M. Winn, Michael L. Parente, David Porter. 2016. Seller Beware: Supply and Demand Reduction and Price Manipulation in Multiple-Unit Uniform Price Auctions. Southern Economic Journal 82:3, 760-780. [Crossref]

25. Daniel L. Chen, Martin Schonger, Chris Wickens. 2016. oTree - An Open-Source Platform for Laboratory, Online, and Field Experiments. SSRN Electronic Journal . [Crossref]

26. Anna Bayona, Xavier Vives. 2016. Supply Function Competition, Private Information, and Market Power: A Laboratory Study. SSRN Electronic Journal . [Crossref]

27. Vinayak V. Dixit, Rami C. Harb, Jimmy Martínez-Correa, Elisabet E. Rutström. 2015. Measuring risk aversion to guide transportation policy: Contexts, incentives, and respondents. Transportation Research Part A: Policy and Practice 80, 15-34. [Crossref]

28. Jonathan E. Alevy, Craig E. Landry, John A. List. 2015. FIELD EXPERIMENTS ON THE ANCHORING OF ECONOMIC VALUATIONS. Economic Inquiry 53:3, 1522-1538. [Crossref]

29. Marco Pagnozzi, Krista Jabs Saral. 2015. Efficiency in Auctions with (Failed) Resale. SSRN Electronic Journal . [Crossref]

30. Vinayak V Dixit, Andreas Ortmann, Elisabet Rutstrom, Satish Ukkusuri. 2015. Understanding Transportation Systems Through the Lenses of Experimental Economics: A Review. SSRN Electronic Journal . [Crossref]

31. Ari Hyytinen, Sofia Lundberg, Otto Toivanen. 2015. Design of Public Procurement Auctions: Evidence from Cleaning Contracts. SSRN Electronic Journal . [Crossref]

32. L. M. Ausubel, P. Cramton, M. Pycia, M. Rostek, M. Weretka. 2014. Demand Reduction and Inefficiency in Multi-Unit Auctions. The Review of Economic Studies 81:4, 1366-1400. [Crossref]

33. Faical Akaichi, Rodolfo M. Nayga, José M. Gil. 2014. Demand reduction in multi-unit auctions with varying number of bidders and units. Economics Letters 124:3, 443-445. [Crossref]

34. Ning Chen, Arpita Ghosh, Nicolas S. Lambert. 2014. Auctions for social lending: A theoretical analysis. Games and Economic Behavior 86, 367-391. [Crossref]

35. Noah C. Dormady. 2014. Carbon auctions, energy markets \& market power: An experimental analysis. Energy Economics 44, 468-482. [Crossref]

36. Levan Elbakidze, Rodolfo M. Nayga, Hao Li, Chris McIntosh. 2014. Value elicitation for multiple quantities of a quasi-public good using open ended choice experiments and uniform price auctions. Agricultural Economics 45:2, 253-265. [Crossref]

37. William Samuelson. Auctions: Advances in Theory and Practice 323-366. [Crossref]

38. Anthony M. Kwasnica, Katerina Sherstyuk. Multiunit Auctions 75-108. [Crossref]

39. Noah C. Dormady. 2013. Market power in cap-and-trade auctions: A Monte Carlo approach. Energy Policy 62, 788-797. [Crossref]

40. Levan Elbakidze, Rodolfo M. Nayga, Hao Li. 2013. Willingness to Pay for Multiple Quantities of Animal Welfare Dairy Products: Results from Random N th-, Second-Price, and Incremental Second- 
Price Auctions. Canadian Journal of Agricultural Economics/Revue canadienne d'agroeconomie 61:3, 417-438. [Crossref]

41. Lijia Shi, Lisa A. House, Zhifeng Gao. 2013. Impact of Purchase Intentions on Full and Partial Bids in BDM Auctions: Willingness-to-pay for Organic and Local Blueberries. Journal of Agricultural Economics 64:3, 707-718. [Crossref]

42. Anthony M. Kwasnica, Katerina Sherstyuk. 2013. MULTIUNIT AUCTIONS. Journal of Economic Surveys 27:3, 461-490. [Crossref]

43. Charles R. Schnitzlein, Minjie Shao. 2013. Capacity constraints and the winner's curse in multi-unit common value auctions. The Quarterly Review of Economics and Finance 53:2, 188-201. [Crossref]

44. Jacob K. Goeree, Theo Offerman, Randolph Sloof. 2013. Demand reduction and preemptive bidding in multi-unit license auctions. Experimental Economics 16:1, 52-87. [Crossref]

45. Jeremy T. Fox,, Patrick Bajari. 2013. Measuring the Efficiency of an FCC Spectrum Auction. American Economic Journal: Microeconomics 5:1, 100-146. [Abstract] [View PDF article] [PDF with links]

46. JANIE M. CHERMAK, KATE KRAUSE, DAVID S. BROOKSHIRE, H. STU BURNESS. 2013. MOVING FORWARD BY LOOKING BACK: COMPARING LABORATORY RESULTS WITH EX ANTE MARKET DATA. Economic Inquiry 51:1, 1035-1049. [Crossref]

47. Marco Pagnozzi, Krista Jabs Saral. 2013. Multi-Object Auctions with Resale: An Experimental Analysis. SSRN Electronic Journal . [Crossref]

48. Christiane Rosen, Reinhard Madlener. 2013. The Role of Information Feedback in Local Reserve Energy Auction Markets. SSRN Electronic Journal . [Crossref]

49. Jakub Kastl. 2012. On the properties of equilibria in private value divisible good auctions with constrained bidding. Journal of Mathematical Economics 48:6, 339-352. [Crossref]

50. Marcelo Olivares, Gabriel Y. Weintraub, Rafael Epstein, Daniel Yung. 2012. Combinatorial Auctions for Procurement: An Empirical Study of the Chilean School Meals Auction. Management Science 58:8, 1458-1481. [Crossref]

51. Yuanguang Yu. 2011. An Optimal Ad Valorem Tax/Subsidy with an Output-Based Refunded Emission Payment for Permits Auction in an Oligopoly Market. Environmental and Resource Economics . [Crossref]

52. Chengyan Yue, Terrance M. Hurley, Neil Anderson. 2011. Do native and invasive labels affect consumer willingness to pay for plants? Evidence from experimental auctions. Agricultural Economics 42:2, 195-205. [Crossref]

53. Ali Hortaçsu. 2011. Recent Progress in the Empirical Analysis of Multi-Unit Auctions\#. International Journal of Industrial Organization . [Crossref]

54. Marcelo Olivares, Gabriel Y. Weintraub, Rafael Epstein, Daniel Yung. 2011. Combinatorial Auctions for Procurement: An Empirical Study of the Chilean School Meals Auction. SSRN Electronic Journal . [Crossref]

55. Paulo B. Goes, Gilbert G. Karuga, Arvind K. Tripathi. 2010. Understanding Willingness-to-Pay Formation of Repeat Bidders in Sequential Online Auctions. Information Systems Research 21:4, 907-924. [Crossref]

56. Marco Pagnozzi. 2010. Are Speculators Unwelcome in Multi-Object Auctions?. American Economic Journal: Microeconomics 2:2, 97-131. [Abstract] [View PDF article] [PDF with links]

57. Kent D. Messer, James J. Murphy. 2010. Special Issue on Experimental Methods in Environmental, Natural Resource, and Agricultural Economics. Agricultural and Resource Economics Review 39:2, iiivi. [Crossref]

58. John A. List, David Reiley. Field Experiments 53-58. [Crossref] 
59. Jeffrey Carpenter, Jessica Holmes, Peter Hans Matthews. Charity auctions in the experimental lab 201-249. [Crossref]

60. Jonathan E. Alevy, Craig E. Landry, John A. List. 2010. Field Experiments on Anchoring of Economic Valuations. SSRN Electronic Journal . [Crossref]

61. John A. List, David Reiley. field experiments 151-156. [Crossref]

62. Axel Ockenfels. 2009. Empfehlungen für das Auktionsdesign für Emissionsberechtigungen. Zeitscbrift für Energiewirtschaft 33:2, 105-114. [Crossref]

63. Dirk Engelmann, Veronika Grimm. 2009. Bidding Behaviour in Multi-Unit Auctions - an Experimental Investigation. The Economic Journal 119:537, 855-882. [Crossref]

64. J. K. Goeree, T. J. S. Offerman, Randolph Sloof. 2009. Demand Reduction and Preemptive Bidding in Multi-Unit License Auctions. SSRN Electronic Journal . [Crossref]

65. Benjamin J. Gillen. 2009. Identification and Estimation of Level-K Auctions. SSRN Electronic Journal . [Crossref]

66. YuenLeng Chow, Abdullah Yavas. 2009. Auctions with Positive Synergies: Experimental Evidence. SSRN Electronic Journal . [Crossref]

67. Veronika Grimm, Axel Ockenfels, Gregor Zoettl. 2008. Strommarktdesign: Zur Ausgestaltung der Auktionsregeln an der EEX. Zeitschrift für Energiewirtschaft 32:3, 147-161. [Crossref]

68. Maurice Doyon, Virginie Simard, Kent D. Messer, Lota D. Tamini, Harry M. Kaiser. 2008. An Experimental Analysis of Modifications to the Centralized Milk Quota Exchange System in Quebec. Canadian Journal of Agricultural Economics/Revue canadienne d'agroeconomie 56:3, 295-312. [Crossref]

69. Matthew C. Rousu, Robert H. Beach, Jay R. Corrigan. 2008. The Effects of Selling Complements and Substitutes on Consumer Willingness to Pay: Evidence from a Laboratory Experiment. Canadian Journal of Agricultural Economics/Revue canadienne d'agroeconomie 56:2, 179-194. [Crossref]

70. P FERRARO. 2008. Asymmetric information and contract design for payments for environmental services. Ecological Economics 65:4, 810-821. [Crossref]

71. Glenn W. Harrison, John A. List. 2008. Naturally Occurring Markets and Exogenous Laboratory Experiments: A Case Study of The Winner's Curse. The Economic Journal 118:528, 822-843. [Crossref]

72. Jason Abrevaya. 2008. On recombinant estimation for experimental data. Experimental Economics 11:1, 25-52. [Crossref]

73. Katerina Sherstyuk. Chapter 23 Some Results on Anti-Competitive Behavior in Multi-Unit Ascending Price Auctions 185-198. [Crossref]

74. John A. List, David Reiley. Field Experiments 1-5. [Crossref]

75. Jeffrey Carpenter, Jessica Holmes, Peter Hans Matthews. 2008. Charity Auctions: A Field Experiment. The Economic Journal 118:525, 92-113. [Crossref]

76. J THRASHER, $M$ ROUSU, $R$ ANAYAOCAMPO, L REYNALESSHIGEMATSU, $E$ ARILLOSANTILLAN, M HERNANDEZAVILA. 2007. Estimating the impact of different cigarette package warning label policies: The auction method. Addictive Bebaviors 32:12, 2916-2925. [Crossref]

77. ATAKELTY HAILU, SOPHIE THOYER. 2007. Designing Multi-unit Multiple Bid Auctions: An Agent-based Computational Model of Uniform, Discriminatory and Generalised Vickrey Auctions. Economic Record 83:s1, S57-S72. [Crossref]

78. Jaeki Song, Jeff Baker. 2007. An integrated model exploring sellers' strategies in eBay auctions. Electronic Commerce Research 7:2, 165-187. [Crossref] 
79. Steven D. Levitt, John A. List. 2007. Viewpoint: On the generalizability of lab behaviour to the field. Canadian Journal of Economics/Revue canadienne d'économique 40:2, 347-370. [Crossref]

80. Charles A. Holt, William Shobe, Dallas Burtraw, Karen L. Palmer, Jacob K. Goeree. 2007. Auction Design for Selling CO2 Emission Allowances Under the Regional Greenhouse Gas Initiative. SSRN Electronic Journal . [Crossref]

81. Doron Sonsino, Radosveta Ivanova-Stenzel. 2006. Experimental internet auctions with random information retrieval. Experimental Economics 9:4, 323-341. [Crossref]

82. Atakelty Hailu, Sophie Thoyer. 2006. Multi-unit auction format design. Journal of Economic Interaction and Coordination 1:2, 129-146. [Crossref]

83. David Porter, Roumen Vragov. 2006. An experimental examination of demand reduction in multiunit versions of the Uniform-price, Vickrey, and English auctions. Managerial and Decision Economics 27:6, 445-458. [Crossref]

84. Paul Resnick, Richard Zeckhauser, John Swanson, Kate Lockwood. 2006. The value of reputation on eBay: A controlled experiment. Experimental Economics 9:2, 79-101. [Crossref]

85. Richard Engelbrecht-Wiggans, Elena Katok. 2006. E-sourcing in Procurement: Theory and Behavior in Reverse Auctions with Noncompetitive Contracts. Management Science 52:4, 581-596. [Crossref]

86. Richard Engelbrecht-Wiggans, John A. List, David H. Reiley. 2006. DEMAND REDUCTION IN MULTI-UNIT AUCTIONS WITH VARYING NUMBERS OF BIDDERS: THEORY AND EVIDENCE FROM A FIELD EXPERIMENT*. International Economic Review 47:1, 203-231. [Crossref]

87. Axel Ockenfels, David H. Reiley, Abdolkarim Sadrieh. Chapter 12 Online Auctions 571-628. [Crossref]

88. C MULLIN, D REILEY. 2006. Recombinant estimation for normal-form games, with applications to auctions and bargaining. Games and Economic Behavior 54:1, 159-182. [Crossref]

89. Matthew C. Rousu, Katherine M. Kosa. 2005. Allowing options in experimental auctions. Applied Economics Letters 12:13, 817-821. [Crossref]

90. John C. Bernard *, William Schulze, Timothy Mount. 2005. Bidding behaviour in the multi-unit Vickrey and uniform price auctions. Applied Economics Letters 12:10, 589-595. [Crossref]

91. Ravi Bapna, Paulo Goes, Alok Gupta. 2005. Pricing and Allocation for Quality-Differentiated Online Services. Management Science 51:7, 1141-1150. [Crossref]

92.S PARK. 2005. Auctions with bidder-determined allowable combinations. European Journal of Operational Research 161:2, 399-415. [Crossref]

93. Richard Engelbrecht-Wiggans, John A. List, David H. Reiley. 2005. Demand Reduction in MultiUnit Auctions: Evidence from a Sportscard Field Experiment: Reply. American Economic Review 95:1, 472-476. [Citation] [View PDF article] [PDF with links]

94. Dan Levin. 2005. Demand Reduction in Multi-Unit Auctions: Evidence from a Sportscard Field Experiment: Comment. American Economic Review 95:1, 467-471. [Citation] [View PDF article] [PDF with links]

95. Svante Mandell. 2005. The choice of multiple or single auctions in emissions trading. Climate Policy 5:1, 97-107. [Crossref]

96. Tanjim Hossain, John Morgan. 2005. A Test of the Revenue Equivalence Theorem using Field Experiments on eBay. SSRN Electronic Journal . [Crossref]

97. Glenn W. Harrison, John A. List. 2004. Field Experiments. Journal of Economic Literature 42:4, 1009-1055. [Abstract] [View PDF article] [PDF with links] 
98. Elena Katok, Alvin E. Roth. 2004. Auctions of Homogeneous Goods with Increasing Returns: Experimental Comparison of Alternative "Dutch" Auctions. Management Science 50:8, 1044-1063. [Crossref]

99. Wendy J. Umberger, Dillon M. Feuz. 2004. The Usefulness of Experimental Auctions in Determining Consumers' Willingness-to-Pay for Quality-Differentiated Products. Review of Agricultural Economics 26:2, 170-185. [Crossref]

100. Jayson L. Lusk, Darren Hudson. 2004. Willingness-to-Pay Estimates and Their Relevance to Agribusiness Decision Making. Review of Agricultural Economics 26:2, 152-169. [Crossref]

101. Jayson L. Lusk, Ty Feldkamp, Ted C. Schroeder. 2004. Experimental Auction Procedure: Impact on Valuation of Quality Differentiated Goods. American Journal of Agricultural Economics 86:2, 389-405. [Crossref]

102. Ronald G. Cummings, Charles A. Holt, Susan K. Laury. 2004. Using laboratory experiments for policymaking: An example from the Georgia irrigation reduction auction. Journal of Policy Analysis and Management 23:2, 341-363. [Crossref]

103. Richard Engelbrecht-Wiggans, Elena Katok. 2004. e-Sourcing in Procurement: Theory and Behavior in Reverse Auctions with Non-Competitive Contracts. SSRN Electronic Journal . [Crossref]

104. Jayson L. Lusk. 2003. Using Experimental Auctions for Marketing Applications: A Discussion. Journal of Agricultural and Applied Economics 35:02, 349-360. [Crossref]

105. Ronald C. Cummings, Charles A. Holt, Susan Laury. 2003. Using Laboratory Experiments for Policy Making: An Example from the Georgia Irrigation Reduction Auction. SSRN Electronic Journal . [Crossref]

106. John A. List. 2002. Preference Reversals of a Different Kind: The "More Is Less" Phenomenon. American Economic Review 92:5, 1636-1643. [Citation] [View PDF article] [PDF with links]

107. Antoni Bosch-Domènech, José G. Montalvo, Rosemarie Nagel, Albert Satorra. 2002. One, Two, (Three), Infinity, ... : Newspaper and Lab Beauty-Contest Experiments. American Economic Review 92:5, 1687-1701. [Citation] [View PDF article] [PDF with links]

108. John A. List, David Lucking-Reiley. 2002. BIDDING BEHAVIOR AND DECISION COSTS IN FIELD EXPERIMENTS. Economic Inquiry 40:4, 611-619. [Crossref]

109. John A. List, Jason F. Shogren. 2002. Calibration of Willingness-to-Accept. Journal of Environmental Economics and Management 43:2, 219-233. [Crossref]

110. John A. List. 2001. Do Explicit Warnings Eliminate the Hypothetical Bias in Elicitation Procedures? Evidence from Field Auctions for Sportscards. American Economic Review 91:5, 1498-1507. [Citation] [View PDF article] [PDF with links]

111. R Bapna. 2001. Comparative analysis of multi-item online auctions: evidence from the laboratory. Decision Support Systems 32:2, 135-153. [Crossref]

112. John A. List. 2001. Determinants of securing academic interviews after tenure denial: evidence from a zero-inflated Poisson model. Applied Economics 33:11, 1423-1431. [Crossref]

113. JA List, CD Bailey, PJ Euzent, TL Martin. 2001. Academic economists behaving badly? A survey on three areas of unethical behavior. Economic Inquiry 39:1, 162-170. [Crossref]

114. A. Fogelgren-Pedersen, K.V. Andersen, M.H. Larsen. Digital auctions: mapping the IT-PAVED roads towards market efficiency 2319-2329. [Crossref]

115. Thomas Kittsteiner, Axel Ockenfels. On the Design of Simple Multi-unit Online Auctions 68-71. [Crossref]

116. William Samuelson. Auctions in Theory and Practice 295-338. [Crossref] 